\title{
Micro-nutrient Contents of Some Fresh Water Fish Species of Manipur, India
}

\author{
HAWAIBAM ROMHARSHA and CHUNGKHAM SAROJNALINI* \\ Fishery Research Laboratory, Centre for Advanced Studies, Department of Life Sciences, \\ Manipur University, Canchipur, Manipur-795003, India. \\ ${ }^{*}$ Corresponding author E-mail: sarojnalini.ch@ gmail.com \\ http://dx.doi.org/10.13005/ojc/350425
}

(Received: May 08, 2019; Accepted: July 13, 2019)

\begin{abstract}
Proximate composition, total amino acid (TAA), mineral and vitamin contents of four fresh water fish species, viz., Bangana devdevi, Gagata dolichonema, Garra abhoyai and Opsarius barnoides were determined. Fish species were collected from different parts of Manipur. The highest moisture and ash content were recorded in 0 . barnoides $(72.59 \pm 0.15 \%$ and $15.47 \pm 0.32 \%$ respectively). The highest total lipid and protein content were recorded in G. dolichonema $(6.50 \pm 0.30 \%$ and $20.99 \pm 1.25 \%$ respectively); while the highest TAA was recorded in $B$. devdevi $(462.38 \pm 1.6 \mathrm{mg} / 100 \mathrm{gm})$. When comparing the mineral contents among the species, good amount of calcium, sodium and iron were recorded in G. dolichonema $(2302.50 \pm 4.95,110.00 \pm 0.29$ and $38.04 \pm 0.03 \mathrm{mg} / 100 \mathrm{gm}$ respectively. Vitamin $A$ and $E$ content were high in $B$. devdevi $(7.04 \pm 0.07$ and $4.08 \pm 0.12 \mathrm{mg} / 100 \mathrm{gm}$ respectively). It could be concluded that, apart from other diets the four species reported from Manipur will provide a good amount of protein, TAA, minerals, vitamin $\mathrm{A}$ and $\mathrm{E}$ in human nutrition.
\end{abstract}

Keywords: Mineral, Vitamin, Freshwater fish, Human nutrition.

\section{INTRODUCTION}

Fish has been an important food item of the people of this region since time immemorial. Fish meat has received increased attention as a potential source of animal protein and essential nutrients for human diet and is regarded superior to other meats in having significantly low lipids and high digestibility protein. Fish is an important source of easily digestible animal protein and other essential micro-nutrients ${ }^{1}$. The nutritional values of fish flesh have a key role in food security and poverty alleviation in developing countries. The chemical composition of fish consists of the major and minor constituents. The analyses of the major constituents of fish is necessary for providing information of the concentrations of protein, lipid, ash and moisture and ensure that they meet the requirements of food regulations and commercial speciation². Fishes are also excellent sources of micro nutrients such as, vitamins and minerals other than protein ${ }^{3}$. There is also lack of knowledge among the people on the facts about the mineral composition of the fishes in the state considering the health related benefits of fish mineral ${ }^{4}$.

This is an Open Access article licensed under a Creative Commons license: Attribution 4.0 International (CC- BY). Published by Oriental Scientific Publishing Company @ 2018 
In Manipur, any types of fish species are consumed in fresh or process ${ }^{5}$. There are some reports about the biochemical composition, minerals, antioxidant and PUFA of fishes ${ }^{5-7,4}$. There are abundant evidences manifesting the significance of fish consumption in brain development, protect vision and eye health, bone maintenance, and protection from cardiovascular diseases and some cancer ${ }^{3}$. But the nutrient content varies from one species to another, and it depends on age, sex, feeding environment and season ${ }^{1}$.

Not only providing the micro-nutrients to human nutrition, fish and fishery also contributes to the diet and nutritional security and income generation of many poor households in underdeveloped and developing countries ${ }^{8,9}$. So, the aim of the current study is to investigate proximate composition, TAA, essential mineral elements and fat soluble vitamin contents of some freshwater fishes of Manipur as an extension to

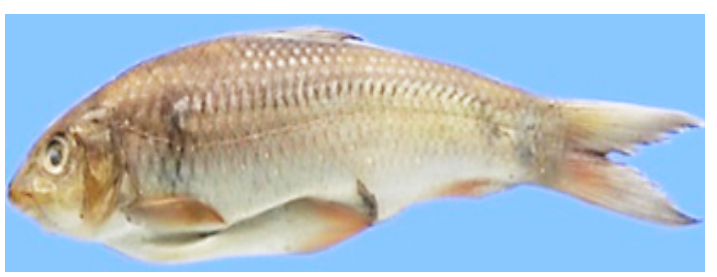

Fig. 1. Bangana devdevi

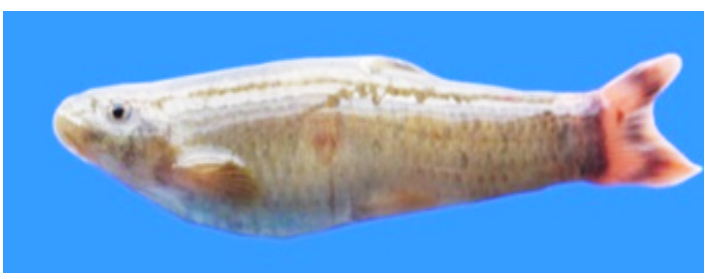

Fig. 3. Garra abhoyai the previous work, to provide knowledge of nutritional value prior to human consumption and food security.

\section{MATERIALS AND METHODS}

\section{Sample collection}

Four different fresh water fish species were collected from different hill districts of Manipur, India during winter season (September-March) for two consecutive years. Bangana devdevi (Fig. 1) was collected from the Moreh market, Chandel district and Gagata dolichonema (Fig. 2) was collected from Iril river, Imphal East district. Garra abhoyai (Fig. 3) was collected from Itok River, Yairipok, Thoubal district, Opsarius barnoides (Fig. 4) was also collected from the Moreh market located at Indo-Burma border, Chandel district. Fig. 5 represents the drainage system of Manipur state, India. Their total length $(\mathrm{cm})$ and weight $(\mathrm{gm})$ were shown in Table 1.

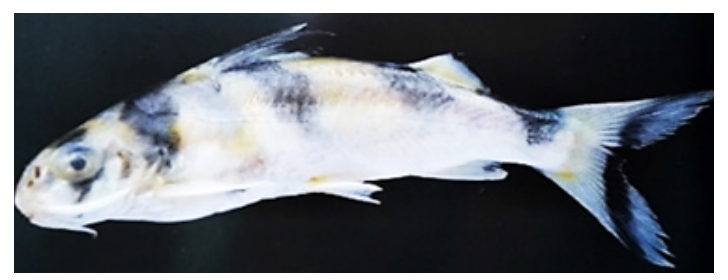

Fig. 2. Gagata dolichonema

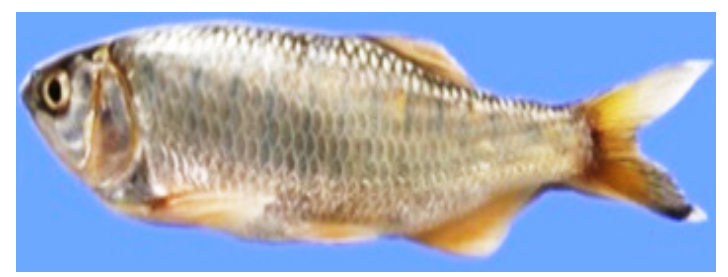

Fig. 4. Opsarius barnoides

Table 1: Fish species with their respective collection sites

\begin{tabular}{|c|c|c|c|c|c|c|}
\hline SI. No. & Collection sites & Scientific names & Local name & No. of samples & $\mathrm{TL}(\mathrm{cm})$ & Weight (g) \\
\hline 1 & Moreh, Chandel district & Bangana devdevi & Khabag & 6 & $13.40-13.90$ & $21.66-22.28$ \\
\hline 2 & Iril river, Imphal East district & Gagata dolichonema & Ngarang/Ngayek & 6 & $07.90-09.80$ & $05.31-07.00$ \\
\hline 3 & Itok river, Thoubal district & Garra abhoyai & Ngamu-Sangum & 6 & 06.01-07.52 & 08.21-10.04 \\
\hline 4 & Moreh, Chandel district & Opsarius barnoides & Ngawa & 6 & $09.30-12.70$ & $07.51-21.63$ \\
\hline
\end{tabular}

After collecting the fish samples from their respective collection sites and they were brought to the Fishery Research Laboratory, Department of Life Sciences, Manipur University, Canchipur by using cold chain. Fishes were washed with running tap water soon after removing from the cold chain. Edible portions of six number of each species of similar sizes were homogenized separately in a mortar-pestle and used for various analyses.

\section{Proximate Compositions}

Moisture was determined by subjecting $1 \mathrm{~g}$ sample in a clean crucible and put in the oven at $105^{\circ} \mathrm{C}$ according to the methods of $\mathrm{AOAC}^{10}$. Total lipid was extracted by homogenizing $1 \mathrm{~g}$ sample with $10 \mathrm{ml}$ chloroform-methanol (2:1) mixture by following the method of Singh et al., ${ }^{11}$. Total nitrogen content was estimated by the method 
of modified Micro-kjedahl ${ }^{10}$. The samples were subjected to digestion; nesslerization and finally absorbance of sample were measured in $440 \mathrm{~nm}$ using UV-Spectrophotometer (Shimadzu, UV-1800, Kyoto, Japan) which were compared with standard concentration of $\left(\mathrm{NH}_{4}\right)_{2} \mathrm{SO}_{4}$ standard $=0.01 \mathrm{mg} / \mathrm{ml}$. Total protein values were obtained by multiplying the nitrogen value with $6.25^{12}$. For the determination of ash content, moisture free samples were ignite at $500^{\circ} \mathrm{C}$ in a muffle furnace for about 2-3 $\mathrm{hr}$ to obtained carbon free white ash as described by $\mathrm{AOAC}^{10}$.

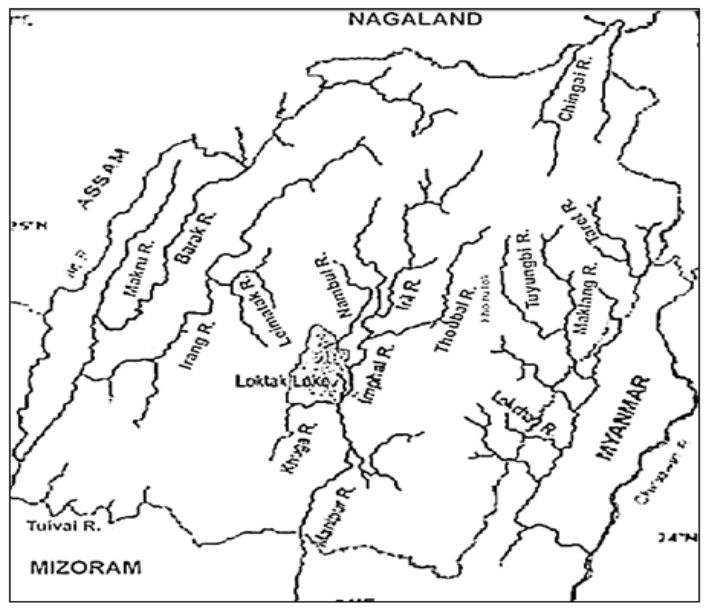

Fig. 5. Drainage system of Manipur (Map not to scale)

\section{Total amino acids (TAA)}

Total amino acid was determined by the method describe by Moore and Stein ${ }^{13}$. Calculation of the amount of total amino acids was done by using standard curve prepared from leucine by pipetting out $0.1-1.0 \mathrm{ml}$ (10-100 $\mu \mathrm{g}$ range) of working standard solution. Results were expressed in $\mathrm{mg} / 100 \mathrm{~g}$ equivalent of leucine.

\section{Mineral analysis}

Essential mineral elements were analyzed following the method of Perkin-Elmer ${ }^{14}$. Accurately weighed ash of respective samples were digested in nitric acid $\left(\mathrm{HNO}_{3}\right)$ and perchloric acid $\left(\mathrm{HClO}_{4}\right)$ and make up to the volume of $50 \mathrm{ml}$ distilled water and subjected to analyze the dissolved mineral content in Atomic Absorption Spectrophotometer (AAS-203).

\section{Vitamin analysis}

Fat soluble vitamin contents were analyzed by using high performance liquid chromatography (HPLC). Fish oil was firstly extracted from the fresh fish meat following the method described by Singh et al.. ${ }^{11}$. About $0.15 \mathrm{~g}$ fish oil was refluxed with $25 \mathrm{~mL}$ methanol and $150 \%$ potassium hydroxide in water bath for 30 minute. Fat soluble vitamins was extracted with $50 \mathrm{~mL}$ petroleum ether. The petroleum ether layer was collected, concentrated and dissolved in $5 \mathrm{~mL}$ acetonitrile. Fat soluble vitamins were analyzed by injecting $20 \mu \mathrm{L}$ of sample in HPLC (Thermo Scientific Dionex UltiMate 3000 ) equipped with C18 RP column and UV detector ${ }^{15}$. The fat soluble vitamins A, D, E, K were identified and quantified by comparing retention times and peak area with those of vitamin standards (Sigma-Aldrich).

\section{Statistical analysis}

The data were analyzed by subjecting to one-way ANOVA at $p \leq 0.05$ using SPSS 16.0 version and the data are presented as mean \pm standard deviation. Pearson's correlation coefficients were also calculated to describe the linear dependence of ash and minerals for the species.

\section{RESULTS AND DISCUSSION}

\section{Proximate composition and TAA analysis}

Proximate composition and TAA of the four fish species were analyzed and the results were shown in Table 2. Moisture, lipid, protein and ash have been expressed in percentage on weight wet basis (wwb) of minced fish flesh. The moisture content among the species ranged from $68.25 \pm 0.25$ to $72.59 \pm 0.15 \%$, the highest was recorded in Opsarius barnoides. The highest protein and relative lipid content were recorded in Gagata dolichonema $(20.99 \pm 1.25 \%$ and $6.50 \pm 0.30 \%$ respectively). G. dolichonema and Garra abhoyai (15.45 $\pm 0.26 \%)$ belonged to the high protein fish category (>15\%) according to the report of $\mathrm{FAO}^{16}$, while the other two species, Bangana devdevi $(10.79 \pm 2.18 \%)$ and $O$. barnoides $(4.58 \pm 0.63 \%)$ can be considered as moderately high protein species. The relatively high to moderate percentage of protein could be attributed to the fact that fishes are good sources of animal protein, and the differences observed in the present study might be due to the consumption capability by the fishes from their diets ${ }^{17}$. The moderate to high protein content of the fish indicates that the studied fish species can be treated as a good source of highly digestible animal protein of high biological value.

The relative lipid content was found in the ranged between $1.37 \pm 0.15$ to $6.50 \pm 0.30 \%$. According to Mohanty et al., ${ }^{18}, \mathrm{O}$. barnoides belong to the lean 
meat (<2\% fat) category, B. devdevi belong to low fat fish (<2-4\% fat) category, while G. dolichonema and G. abhoyai belong to the medium fat fish (4-8\% fat) category. Ash content was estimated to be ranged from $10.56 \pm 0.35$ to $15.47 \pm 0.32 \%$ and is positively correlated with $\mathrm{Ca}, \mathrm{Mg}, \mathrm{Na}, \mathrm{K}, \mathrm{Cu}$ and $\mathrm{Zn}$ content with correlation coefficients of $0.035,0.087,0.018$, $0.008,0.006$ and 0.070 respectively.

Table 2: Proximate composition of the four freshwater fish species of Manipur

\begin{tabular}{cccccc}
\hline Species & Moisture & Lipid & Protein & Ash & TAA (mg/100g) \\
\hline Bangana devdevi & $69.23 \pm 0.09$ & $2.53 \pm 0.11$ & $10.79 \pm 2.18$ & $11.97 \pm 0.32$ & $462.38 \pm 1.6$ \\
Gagata dolichonema & $72.52 \pm 1.27$ & $6.50 \pm 0.30$ & $20.99 \pm 1.25$ & $13.60 \pm 0.26$ & $275.27 \pm 1.3$ \\
Garra abhoyai & $68.25 \pm 0.39$ & $5.83 \pm 0.15$ & $15.45 \pm 0.26$ & $10.56 \pm 0.35$ & $297.00 \pm 0.0$ \\
Opsarius barnoides & $72.59 \pm 0.15$ & $1.37 \pm 0.15$ & $4.58 \pm 0.63$ & $15.47 \pm 0.32$ & $437.62 \pm 1.6$ \\
\hline
\end{tabular}

Values are mean of 3 replicates.

Mean \pm S.D. followed the same letter are not significantly different $(p \leq 0.05)$.

In the present study, TAA content was found ranged from $275.27 \pm 1.3$ to $462.38 \pm 1.6$ $\mathrm{mg} / 100 \mathrm{~g}$. The highest TAA content was recorded in B. devdevi $(462.38 \pm 1.6 \mathrm{mg} / 100 \mathrm{~g})$, while the lowest in G. dolichonema $(275.27 \pm 1.3 \mathrm{mg} / 100 \mathrm{~g})$. The amount of TAA content in the fish depends on the availability of food.

\section{Essential mineral elements}

Essential mineral element contents showed an important role on nutritional quality of fish. Fish provides essential mineral elements such as calcium, magnesium, sodium, phosphorus, zinc, iron, selenium and iodine to human nutrition ${ }^{19}$. The essential mineral profiles of four species are presented in Table 3. Among the four species, Gagata dolichonema appeared to be a good source of $\mathrm{Ca}, \mathrm{Na}$ and $\mathrm{Fe}(2302.5 \pm 4.95,110.00 \pm 0.29$ and $38.04 \pm 0.03 \mathrm{mg} / 100 \mathrm{~g}$ respectively). The calcium content ranging from $164.38 \pm 1.95$ to $2302.5 \pm 4.95$ $\mathrm{mg} / 100 \mathrm{~g}$ in this study is very much similar with some other fish species found in the state and is positively correlated with the ash content with coefficient of 0.035 . It was reported that, the calcium content of Cabdio ukhrulensis, Raiamas guttatus, Salmostoma sladoni, Schistura khugae and Systomus clavatus found in the state were $860.94 \pm 1.3,2023.50 \pm 4.24$, $1861.00 \pm 2.60,1598.50 \pm 4.00$ and $1405.20 \pm 3.18$ $\mathrm{mg} / 100 \mathrm{~g}$ respectively ${ }^{4}$. According to Recommended Dietary Allowances (RDA) ${ }^{20}$, calcium requirement by an adult Indian is $600-1200 \mathrm{mg} /$ day. The data mentioned here clearly indicates that, these fresh water fish species are good source of calcium and it can be assumed that regular intake of these fish species will help in the strength of bones, teeth, muscles and nervous system. Sodium content was found ranging from $70.00 \pm 0.24$ to $110.00 \pm 0.29$ $\mathrm{mg} / 100 \mathrm{~g}$ and the highest was observed in G. dolichonema. The mean concentration of sodium in the study falls within mean ranges of 30-134 $\mathrm{mg} / 100 \mathrm{~g}$ as reported by Food and Agricultural Organization $(F A O)^{16}$. It is also very much similar with the sodium content of some other fresh water fishes of the state. According to Romharsha ${ }^{4}$, sodium content was found in the range of $87.50 \pm 0.19$ to $107.60 \pm 0.08 \mathrm{mg} / 100 \mathrm{~g}$. The sodium content in this study is also positively correlated with the ash content with coefficient of 0.018 .

The mean concentration of potassium among the species ranged from $95.00 \pm 0.24$ to $137.50 \pm 0.29 \mathrm{mg} / 100 \mathrm{~g}$ which again falls within the mean ranges of $19-502 \mathrm{mg} / 100 \mathrm{~g}$ as reported by $\mathrm{FAO}^{16}$ and is positively correlated with the ash content with coefficient of 0.008 . In the previous study ${ }^{4}$, the mean concentration of potassium in some fresh water fishes was found in the range of $87.50 \pm 0.19$ to $107.60 \pm 0.08 \mathrm{mg} / 100 \mathrm{~g}$. The highest magnesium content in the study was recorded in O. barnoides $(311.00 \pm 1.32 \mathrm{mg} / 100 \mathrm{~g})$ and the lowest in $B$. devdevi $(58.10 \pm 0.96 \mathrm{mg} / 100 \mathrm{~g})$. The magnesium content in this study is again positively correlated with the ash content with coefficient of 0.087 .

The average manganese, copper, zinc and iron content in this study ranges from $0.32 \pm 0.01$ to $1.99 \pm 0.02 \mathrm{mg} / 100 \mathrm{~g}, 0.20 \pm 0.01$ to $0.32 \pm 0.01$ $\mathrm{mg} / 100 \mathrm{~g}, 0.17 \pm 0.02$ to $2.59 \pm 0.01 \mathrm{mg} / 100 \mathrm{~g}$ and $8.65 \pm 0.03$ to $38.04 \pm 0.03 \mathrm{mg} / 100 \mathrm{~g}$ respectively. The highest amount of manganese was observed in G. abhoyai, copper in B. devdevi, zinc in O. barnoides and iron in $G$. dolichonema. The copper and zinc content in this study is positively correlated with the ash content with coefficient of 0.006 and 0.070 respectively. 
Table 3: Essential mineral elements of the four freshwater fish species of Manipur

\begin{tabular}{ccccc}
\hline Trace Minerals $(\mathrm{mg} / 100 \mathrm{~g})$ & \multicolumn{3}{c}{ Species } \\
& Bangana devdevi & Gagata dolichonema & Garra abhoyai & Opsarius barnoides \\
\hline $\mathrm{Ca}$ & $164.38 \pm 1.95$ & $2302.5 \pm 4.95$ & $1473.5 \pm 2.21$ & $1612.50 \pm 1.21$ \\
$\mathrm{Mg}$ & $58.10 \pm 0.96$ & $93.00 \pm 1.52$ & $96.50 \pm 1.75$ & $311.00 \pm 1.32$ \\
$\mathrm{Na}$ & $70.00 \pm 0.24$ & $110.00 \pm 0.29$ & $80.00 \pm 0.34$ & $92.50 \pm 0.11$ \\
$\mathrm{~K}$ & $137.50 \pm 0.29$ & $137.50 \pm 0.22$ & $95.00 \pm 0.24$ & $120.00 \pm 0.23$ \\
$\mathrm{Mn}$ & $0.32 \pm 0.01$ & $0.51 \pm 0.02$ & $1.99 \pm 0.02$ & $0.77 \pm 0.02$ \\
$\mathrm{Cu}$ & $0.32 \pm 0.01$ & $0.30 \pm 0.02$ & $0.20 \pm 0.01$ & $0.24 \pm 0.02$ \\
$\mathrm{Zn}$ & $2.18 \pm 0.07$ & $2.43 \pm 0.02$ & $0.17 \pm 0.02$ & $2.59 \pm 0.01$ \\
$\mathrm{Fe}$ & $21.74 \pm 0.06$ & $38.04 \pm 0.03$ & $30.71 \pm 0.01$ & $8.65 \pm 0.03$ \\
\hline
\end{tabular}

Values are mean of 3 replicates.

Mean \pm S.D. followed the same letter are not significantly different $(p \leq 0.05)$

The result of the present study clearly indicates that the most abundant macro mineral elements in Bangana devdeviare potassium, calcium and sodium in $G$. dolichonema and magnesium in Opsarius barnoides. While the micro mineral elements like copper, iron, manganese and zinc were found more abundant in B. devdevi, G. dolichonema, Garra abhoyai and $O$. barnoides respectively.

\section{Vitamin}

Each type of fat-soluble vitamin promotes different functions in the body. Fish provides vitamins $A, D$ and $B$ to human nutrition, thereby decrease the risk of malnutrition among children and pregnant woman ${ }^{19}$. Fat soluble vitamin contents of the four fish species are presented in Table 4. Vitamin A plays an important role in maintaining healthy vision and immune system. Vitamin A does not refer to one single vitamin, but is a collection of compounds known as retinoid. Vitamin A supports several functions throughout the body. Common symptoms of its deficiency include hair loss, blindness, reduced immune system and skin issues. So, one should obtained through regular food intake. In the present study, vitamin A content was found significantly high $(p \leq 0.05)$ in Bangana devdevi $(7.04 \mathrm{IU} / 100 \mathrm{~g})$, followed by Opsarius barnoides $(2.78 \mathrm{lU} / 100 \mathrm{~g})$ and the lowest in Garra abhoyai $(0.08 \mathrm{IU} / 100 \mathrm{~g})$. In some fresh water fishes of India, vitamin A content were found as $12.2 \pm 4.5 \mathrm{IU} / 100 \mathrm{~g}$ in Catla catla, 8.7 $\pm 2.2 \mathrm{IU} / 100 \mathrm{~g}$ in Labeo rohita and $3.9 \pm 1.1 \mathrm{IU} / 100 \mathrm{~g}$ in Clarias batracus ${ }^{21}$.

Vitamin $D$ is required for bone maintenance and immune system support. Fatty fish are a good source of vitamin $D$, which is essential for bone health ${ }^{22}$. Vitamin $D$ can be produced in the human body by exposing our skin to the sun. However, many people do not spend hours in the sun to produce vitamin D. Common symptoms of vitamin D deficiency include weakened immune system, impaired healing, soft bones, tiredness, etc. So, one should obtained from food sources like fish oil. In the present study, vitamin D content was found in the following order: $94800 \pm 65.82 \mathrm{IU} / 100$ $\mathrm{g}$ in Gagata dolichonema $>32400 \pm 90.06 \mathrm{IU} / 100$ $\mathrm{g}$ in Garra abhoyai > 25200 $\pm 91.80 \mathrm{IU} / 100 \mathrm{~g}$ in Opssarius barnoides $>10400 \pm 91.01 \mathrm{IU} / 100 \mathrm{~g}$ in Bangana devdevi. According to Mohanty et al., ${ }^{21}$, vitamin D content in Amblypharyngodon mola was 93122.4 $\pm 89.2 \mathrm{IU} / 100 \mathrm{~g}$, in Puntius sophore was $16266.4 \pm 84.2 \mathrm{IU} / 100 \mathrm{~g}$, in Sperata seenghala was $7494.8 \pm 56.3 \mathrm{IU} / 100 \mathrm{~g}$ and in Tenualosa ilisha was $9549 \pm 85.2 \mathrm{lU} / 100 \mathrm{~g}$.

Table 4: Fat soluble vitamin contents of the four freshwater fish species of Manipur

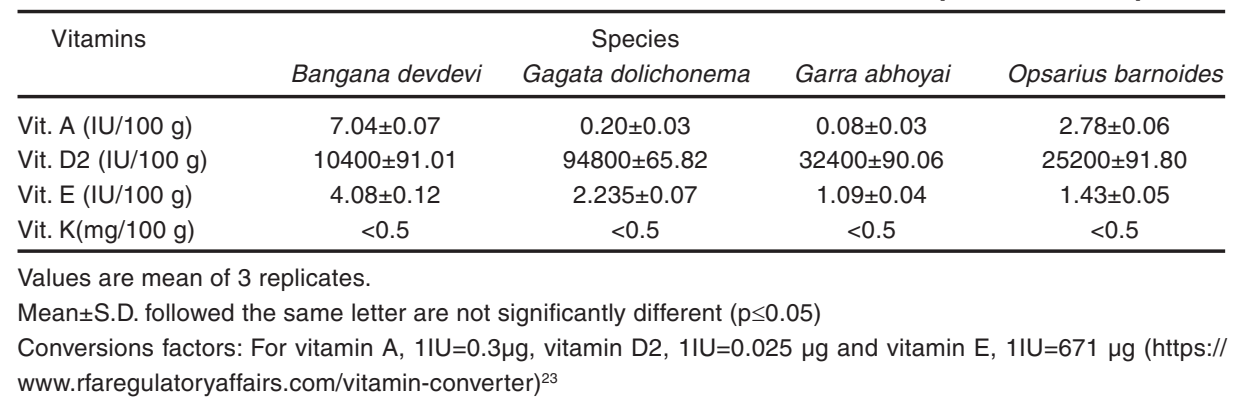


Vitamin $\mathrm{E}$ is an antioxidant that can help the body destroy free radicals. As an antioxidant, vitamin $E$ protects fatty tissues from free radicals that can cause cancer. Common symptoms of vitamin E deficiency include muscle weakness, numbness, trouble walking, anemia, heart disease, etc. In this study, vitamin $E$ content was recorded as $4.08 \pm 0.12 \mathrm{IU} / 100 \mathrm{~g}$ (Bangana devdevi), $2.23 \pm 0.07$ $\mathrm{IU} / 100 \mathrm{~g}$ (Gagata dolichonema), $1.43 \pm 0.05 \mathrm{IU} / 100 \mathrm{~g}$ (Opsarius barnoides) and $1.09 \pm 0.04 \mathrm{IU} / 100 \mathrm{~g}$ (Garra abhoyai). The result is highly similar with the vitamin E content in Amblypharyngodon mola (2.2 \pm 0.1 $\mathrm{IU} / 100 \mathrm{~g})$, Puntius sophore $(3.4 \pm 0.3 \mathrm{IU} / 100 \mathrm{~g})$ and Anabas testudineus $(0.9 \pm 0.1 \mathrm{lU} / 100 \mathrm{~g})$ as reported by Mohanty et al., ${ }^{21}$.

Vitamin $\mathrm{K}$ helps the body in blood clotting from injuries, bone metabolism and regulating blood calcium levels. The body needs vitamin $\mathrm{K}$ to produce prothrombin, a protein and clotting factor that is important in blood clotting and bone metabolism. Person with vitamin $\mathrm{K}$ deficiency have a greater risk of uncontrolled bleeding and reduce bone density that can lead to fractures. So, vitamin $\mathrm{K}$ is also an important micronutrient needed by our body. In all the four species studied, vitamin $\mathrm{K}$ was recorded as low as $<0.5 \mathrm{mg} / 100 \mathrm{~g}$ which is similar with some other fresh water fishes found in India.

\section{CONCLUSION}

This study provides the basic information about proximate composition, TAA, macro and micro mineral elements and fat soluble vitamin contents of four fresh water fishes of Manipur. It can be concluded that, these fish species are significant sources of protein, some essential mineral elements and fat soluble vitamins, and can be used as a supplementary diet in human nutrition. Micronutrient content is high in small fish species because they are consumed as a whole. The information generated would be useful to the people of the region regarding the nutritional significance of consuming fish. It may also be useful for further documentation, production and conserving of high quality fishes.

\section{ACKNOWLEDGEMENT}

The authors thank to the Head of the Department of Life Sciences, Manipur University for providing laboratory facilities. They also greatly appreciate the colleagues of the Fishery Research Laboratory for giving cooperation during the entire work was done.

\section{Conflict of interest}

There is no conflict of interest.

\section{REFERENCES}

1. Sarma, D., Das, P.D., Das, P., Bisht, H.C.S., Akhtar, M.S. and Ciji, A. Fatty acid, amino acid and mineral composition of rainbow trout (Oncoryhynchus mykiss) of Indian Himalaya. Indian J. Anim. Res., 2015, 49(3) 399-404.

2. Sutharshiny, $S$ and K. Sivashanthini. Proximate composition of three species of Scomberoides fish from Sri Lankan Waters. Asian J. Clin. Nutri., 2011, 3, 103-111.

3. Sarkar, T.V., Ananda, R., Mathew, S., Asha, K.K., Lakshmanan, P.T., Varkey, J., Aneesh, P. and Mohanty, B.P. (2013) Chemical composition and nutritional value of Anchovy (Stolephorus commersonii) caught from Kerela coast, India. European journal of experimental biology., 2013, 3(1) 85-89.

4. Romharsha, $\mathrm{H}$. and Sarojnalini, Ch. Proximate Composition, Total Amino Acids and Essential Mineral Elements of Some Cyprinid Fishes of Manipur, India. Current Research in nutrition and Food Science., 2018, 06(1), 157-164.

5. Sarojnalini, Ch. Nutritive Values of Two Indigenous Cobitid Fishes Botia berdmorei and Lepidocephalus guntea of Manipur. The Bioscan, An Internaltional Quaterly Journal in Life Sciences., 2010, 2, 391-396.

6. Sarjubala, $W$ and Sarojnalini, Ch. Impact of different cooking methods on proximate and mineral composition of Amblypharyngodon mola. International Journal of Advanced Biological Research., 2012, 2(4), 712-716.

7. Sarojnalini, Ch and Sarjubala, W. Antioxidant properties and nutritive values of raw and cooked Pool barb (Puntius sophore) of Eastern Himalayas. International Journal of Agricultural, Biosystems Science and Engineering., 2014, 8(1), 13-17.

8. Thompson, B. and Amoroso, L., eds. Improving diets and nutrition: food based approaches. Rome, FAO., 2014. 
9. Béné, C., Devereux, S. and Roelen, K. Social protection and sustainable natural resource management: initial findings and good practices from small-scale fisheries. FAO Fisheries and Aquaculture Circular No. 1106. Rome, FAO., 2015.

10. AOAC. Official methods of Analysis of association of analytical chemist (16th ed.). Washington DC: AOAC., 2000.

11. Singh B, Sarojnalini $\mathrm{CH}$ and Vishwanath $\mathrm{W}$. Nutritive values of sundried Esomus danricus and smoked Lepidocephalus guntea. Food Chem., 1990, 36, 89-96.

12. Osborne, DR and Voogt, TP. Analysis of nutrients in foods. Academia Press, New York., 1978.

13. Moore, S and W.H Stein. In: Methods Enzymol. (Eds. Colowick, S.P and Kaplan, N.D), Academic press, New York., 1948, 3 (468), 9(1), 1-5.

14. Perkin-Elmer. Analytical Methods for Atomic Absorption Spectroscopy. The PerkinElmer Inc. U.S.A., 1996.

15. Chatzimichalakis, PM., Samanidou, VF. And Papadoyannis, JN. Development of validated liquid chromatography method for the simultaneous determination of eight-fat soluble vitamins in biological fluids after solid-phase extraction. J. Chromatog. B., 2004. 805, 289-296.

16. FAO/WHO. Human vitamin and mineral requirements, Rome: FAO., 2001.

17. Burgress. GHO. Increasing the direct consumption of fish. In: Pirie WW (Edu). Food Protein Sources. International Biological Program 4. Cambridge University Press, Cambridge., 1975, 187-200.

18. Mohanty, B.P., Sankar, T.V., Ganguly, S., Mahanty, A., Anandan, R., Chakraborty, K.,
Paul, B.N., Sarma, D., Dayal, J.S., Mathew, S., Asha, K.K., Mitra, T., Karunakaran, D., Chanda, S., Shahi, N., Das, P., Das, P., Akhtar, M.S., Vijaygopal, P. and Sridhar, N. 2016. DHA and EPA content and fatty acid profile of 39 food fishes from India. BioMed Research International. http://dx.doi. org/10.1155/2016/4027437

19. Allison, E.H., Delaporte, A. and Hellebrandt de Silva, D. Integrating fisheries management and aquaculture development with food security and livelihoods for the poor. Report submitted to Rockefeller Foundation. Norwich, UK, School of International Development, University of East Anglia., 2013.

20. RDA. Nutrient requirements and recommended dietary allowances for Indians: A report. National Institute of Nutrition. Indian Council of Medical Research, Hyderabad., 2010.

21. Mohanty, B.P., Sankar, T.V., Ganguly, S., Mahanty, A., Anandan, R., Chakraborty, K., Paul, B.N., Sarma, D., Dayal, J.S., Mathew, S., Asha, K.K., Mitra, T., Karunakaran, D., Chanda, S., Shahi, N., Das, P., Das, P., Akhtar, M.S., Vijaygopal, P. and Sridhar, N. 2016. Micronutrient composition of 35 Food Fishes from India and their significance in human nutrition. Biol. Trace Elem. Res. DOI: 10.1007/s12011-016-0714-3.

22. FAO. The State of World Fisheries and Aquaculture. Contributing to food security and nutrition for all. Rome., 2016, 200.

23. https://www.rfaregulatoryaffairs.com/vitaminconverter (Robert Forbes and Associates regulatory and technical advisory, Australia) 